\title{
Minimally Invasive Cardiac Surgery Experiences in a District Branch Hospital
}

Tanıl Özer, Murat Yücel, İlker Mataracı, Muhammet Onur Hanedan, Ufuk Sayar, İzzet Emir

Ahi Evren Thoracic and Cardiovascular Surgery Training and Research Hospital, Clinic of Cardiovascular Surgery, Trabzon, Turkey

\begin{abstract}
Introduction: With the development of technology and surgical experiences, minimally invasive approaches are getting more preferable by physicians. Also these smaller incisions provide patients to have higher life quality at their postoperative periods. In this study we aimed to report our minimally invasive approach experiences.

Patients and Methods: In our clinic 10 patients underwent open heart surgery with minimally invasive approaches between March 2010 and January 2014. The mean age was 50.5 26 years (range, 22-82 years). Six of them were females $(60 \%)$. Four patients have had previous open heart surgery through standard sternotomy. Ministernotomy was performed in 4 patients, 5 patients' operations were done via right anterior mini-thoracotomy and one patient was operated via left anterior minithoracotomy.

Results: The mean operation duration was 6.8 \pm 1.8 hours (range, 4-10 hours) (time elapsed from anesthesia induction to wound closure with sterile sponge). Only one patient was extubated in operating theatre. Early mortality (in postoperative 30 days) was seen in only one patient. One patient was admitted to hospital with wound complication and re-hospitalized for wound care.

Conclusion: With developments in cardiac surgery field, many disorders are repaired via minimally invasive techniques providing exposures as good as conventional approaches. In recent years, many clinics reported their experiences at these applications with excellent results. Minimally invasive cardiac surgery does not have worse mortality rates than standard techniques. Also, it enables patients to return to their own normal activities, providing them with less wound complications. With the increasing experiences, minimally invasive cardiac surgery may be considered in those appropriate patients and particularly in patients who care about their own appearances.
\end{abstract}

Key Words: Minimally invasive cardiac surgery; open heart surgery

\section{Bir Bölge Dal Hastanesinin Minimal İnvazif Kalp Cerrahisi Deneyimleri}

\section{ÖZET}

Giriş: Teknolojik ve cerrahi alandaki gelişmelerle, minimal invazif cerrahi yaklaşımlar hekimler için daha fazla tercih edilebilir hal almışlardır. Aynı zamanda bu küçük kesiler hastaların postoperatif dönemdeki hayat kalitesini de arttırmıştır. Bu çalışma ile bir bölge dal hastanesi olarak bu alandaki deneyimlerimizi bildirmek istedik.

Hastalar ve Metod: Mart 2010 ile Nisan 2014 arası 10 hasta hastanemizde minimal invazif yaklaşımla opere edildi. Altısı (\%60) bayan olan hastaların yaş ortalaması 50,5 26 yıl (22-82) idi. Dört hastaya ministernotomi, 5 hastaya sağ bir hastaya sol anteriyor minitorakotomi uygulandi.

Bulgular: Ortalama operasyon süresi 6,8 $\pm 1,8$ saat (4-10 saat) (anestezi indüksiyonundan yaranın steril gazlı bez ile kapatılmasına kadar geçen süre). Sadece bir hasta ameliyathanede ekstübe edildi. Erken mortalite (postoperatif ilk 30 gün) sadece bir hastada görüldü. Bir hasta yara yeri komplikasyonu nedeniyle yeniden hospitalize edildi. Sonuç: Kardiyak cerrahi alandaki gelişmeler ile birçok bozukluk konvansiyonel yöntemler kadar iyi görüş sağlayan minimal invazif tekniklerle ameliyat edilebilmektedir. Son yıllarda birçok klinik bu alanda gayet güzel sonuçlarını yayınlamışlardır. Sonuçlar da gösteriyor ki, minimal invazif yaklaşım standart tekniklerden daha kötü sonuçları olmamakla beraber hastaların normal yaşam aktivitelerine dönüşlerini kolaylaştırıp, yara yeri komplikasyonlarını da azaltmaktadır. Artan deneyimlerle beraber özellikle dış görünümüne önem veren uygun hastalarda minimal invazif yaklaşımlar akılda bulundurulmalıdır.

Anahtar Kelimeler: Minimal invazif kalp cerrahisi; açık kalp cerrahisi

\section{Correspondence}

Tanıl Özer

E-mail: drtanilozer@gmail.com Submitted: 06.06 .2014 Accepted: 24.06 .2014

(a) Copyright 2014 by Koşuyolu Heart Journal - Available on-line at www.kosuyolukalpdergisi.com

\section{INTRODUCTION}

Most of cardiac surgical procedures are still performed through standard incisions. These incisions enabling operators achieve better exposures and therefore feel more confident themselves. However, patients' satisfactory is not as much as ours. With the development of technology and surgical experiences, minimally invasive approaches are getting more preferable by physicians. Also these smaller incisions provide patients to have higher life quality at the postoperative periods $(1,2)$. In this study we aim to report our minimally invasive approach experiences. 


\section{PATIENDS and METHODS}

In our clinic 10 patients has underwent open heart surgery with minimally invasive approaches between March 2010 and January 2014. Median age was $50.5 \pm 26$ years (22-82 years). Six of them were female $(60 \%)$. Four patients have had previous open heart surgery through standard sternotomy. Ministernotomy was performed for 4 patients who were performed aortic valve replacement (AVR), 5 patients' operations were done via right anterior minithoracotomy and one patient underwent coronary artery bypass grafting (CABG) via left anterior minithoracotomy (Table 1). One patient who had underwent mitral valve replacement (MVR), AVR and tricuspid valve ring annuloplasty 6 years ago was operated urgently after the diagnosis of prosthesis valve dysfunction. This patient also supported by extracorporeal membrane oxygenation (ECMO) at the postoperative period.

\section{Surgical Techniques}

In upper ministernotomy group; a nearly $6-8 \mathrm{~cm}$ length midline skin incision was made starting from suprasternal notch. Sternum was divided down to the fourth intercostal space and angled right with an oscillating saw (J shape). A Finochietto sternal retractor was used to separate the sternal edges. The remnant thymus gland and/or fatty tissues were excised to improve the exposure. The pericardium was opened sufficiently and suspended to exposure the aorta and left ventricular outflow tract. The arterial cannulation was made to distal part of the ascending aorta with conventional technique. The venous cannulation was performed from femoral vein percutaneously. The cross clamping and cardioplegia applications were done via conventional technique. Aortic valve's exposure was as good as standard full sternotomy. A 36 Fr drainage tube was placed to the mediastinal cavity lying undersurface of the sternum (Figure 1).

\begin{tabular}{|c|c|c|c|c|c|}
\hline Patient & & Age/Gender & BMI & $\begin{array}{l}\text { Type of } \\
\text { Pathology }\end{array}$ & Re-Operation \\
\hline \multicolumn{6}{|c|}{ Mini Sternotomy } \\
\hline 1 & & $24 / \mathrm{M}$ & 21.2 & $\mathrm{AR}$ & - \\
\hline 2 & & $72 / \mathrm{M}$ & 21.6 & AS & - \\
\hline 3 & & $72 / \mathrm{F}$ & 43.3 & AS & - \\
\hline 4 & & $82 / \mathrm{M}$ & 29.4 & AS & + \\
\hline \multicolumn{6}{|c|}{ Mini Thoracotomy } \\
\hline 1 & & $22 / \mathrm{F}$ & 21.4 & M PVD, TR & + \\
\hline 2 & & $23 / \mathrm{M}$ & 21.8 & ASD & + \\
\hline 3 & & $23 / \mathrm{F}$ & 21.5 & ASD & - \\
\hline 4 & & $43 / \mathrm{F}$ & 19.3 & $\mathrm{MR}, \mathrm{AR}$ & - \\
\hline 5 & & $71 / \mathrm{F}$ & 26.0 & MR,TR & + \\
\hline 6 & & $73 / \mathrm{F}$ & 30.5 & CAD & - \\
\hline Total & 10 & & & & \\
\hline Mean & & 50.5 & 25.6 & & \\
\hline
\end{tabular}

AR: Aortic regurgitation, AS: Aortic stenosis, ASD: Atrial septal defect, CAD: Coronary artery disease, F: Female, M: Male, M PVD: Mitral prosthesis valve dysfunction, MR: Mitral regurgitation, TR: Tricuspid regurgitation
In anterior minithoracotomy group; left anterior minithoracotomy was made to patient operated for CABG and right anterior minithoracotomy was made to the others. The submammarian groove was used for the anterolateral incision (Figure 2). CABG was performed at the beating heart. Internal mamarian artery was prepared through thoracotomy and anastomosed to anterior descending coronary artery by using Genzyme retractor. Right femoral artery for arterial cannulation, right femoral and jugular veins for venous cannulation were used to the patients whose operations were performed under cardiopulmonary bypass (CPB). Pericardium was opened nearly $2 \mathrm{~cm}$ anterior of phrenic nerve to save from retraction's injury and traction sutures placed to exposure the caval veins, ascending aorta, pulmonary veins and the left atrium. Chitwood cross clamp was placed with Chitwood technique. Antegrade cardioplegia was administered with aortic root needle.

All operations were performed using the same anesthesia protocol, moderate hypothermic $\mathrm{CPB}\left(30{ }^{\circ} \mathrm{C}\right.$ to $\left.32{ }^{\circ} \mathrm{C}\right)$ and isothermic blood cardioplegia.

\section{Statistics Analysis}

No statistical tests were used. Data was expressed as mean \pm standard deviation.

\section{RESULTS}

Mean operation duration was $6.8 \pm 1.8$ hours (4-10 hours) (from anesthesia induction to wound closure with sterile sponge)

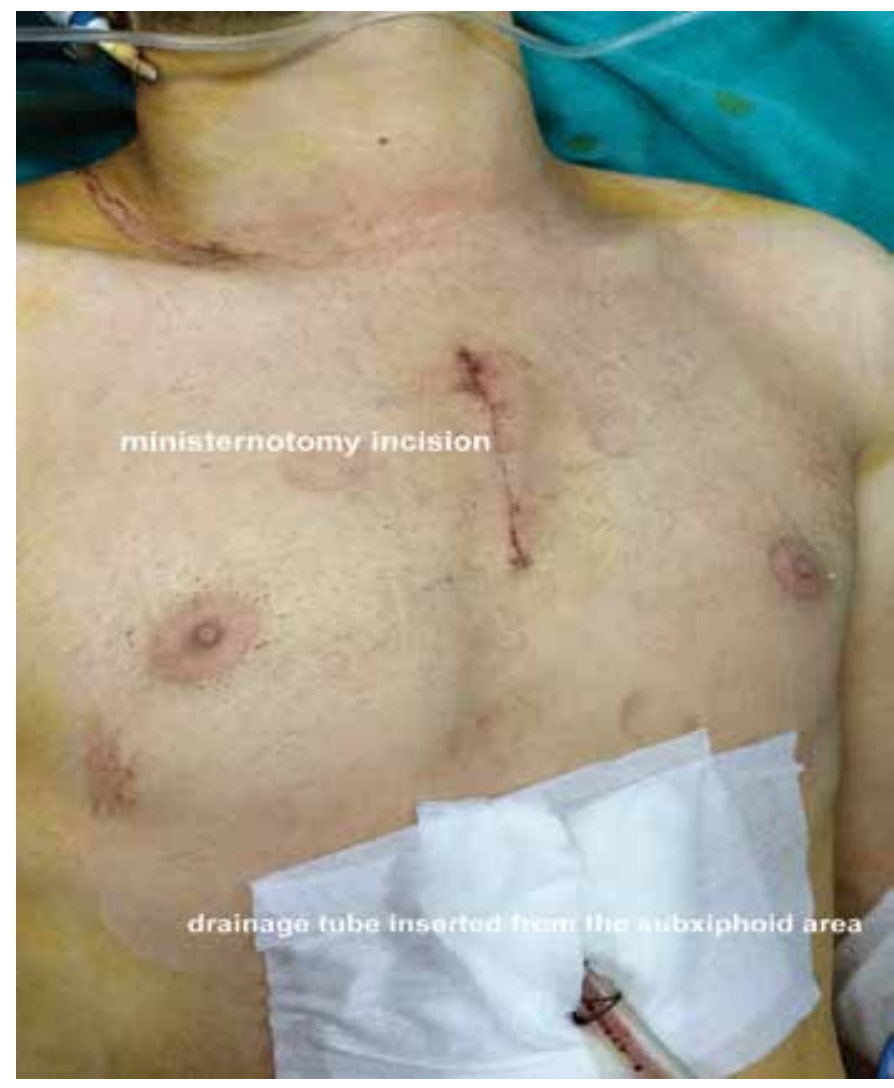

Figure 1. Postoperative view of Ministernotomy 
(Table 1). Only one patient was extubated in operating theatre. Early mortality (in postoperative 30 days) was seen on only one patient who had undergone CABG 16 years ago and aortic and innominate vein injuries were occurred peroperatively. This patient could not wean from CPB. One patients hospitalization extended by the cause of atrial fibrillation (AF). One patient who was performed ECMO at the postoperative period hospitalized for about one month. She was discharged from hospital in a healthy status. One patient was admitted to hospital with wound complication and re-hospitalized for wound care.

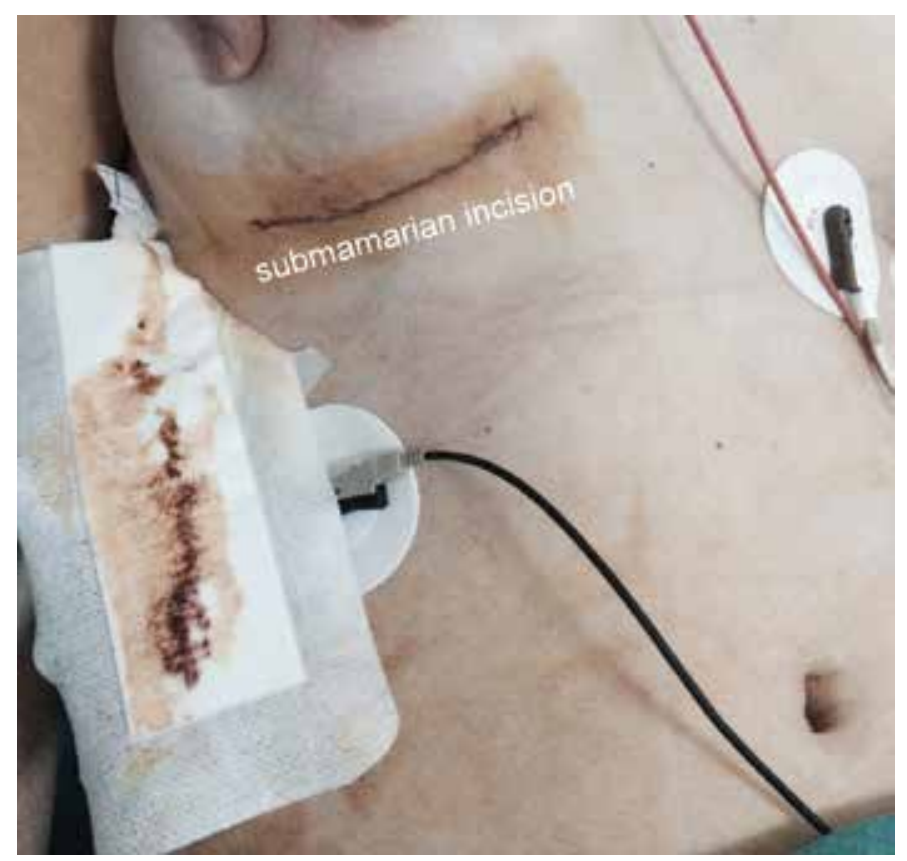

Figure 2. Postoperative view of minithoracotomy

\section{DISCUSSION}

With developments in cardiac surgery field, many disorders are repaired via minimally invasive techniques providing exposures as good as conventional approaches( 1 ). In recent years, many clinics reported their experiences at these applications with excellent results. From ASD repairment to $\mathrm{CABG}$ and/or three valve repairments, many cardiac surgical procedures can be performed via minimally invasive approaches(3-6). As shown in the Table 2, our cases which include four redo surgeries had the nearly same complexity scale as the world.

While exerting effort to minimize the incisions, we know that the importance of providing outcomes at least as good as conventional approaches. In the literature there are so many reports showing good results about minimally invasive cardiac surgery. Moreover, some reports have included complex cases $(4,6,7)$. In addition to these good results, one of the most focused issue was patient satisfactory. Cosmetic reasonsespecially for young women - gain importance to prefer these smaller incisions $(1,3)$. Komai et al. described a lower small midline skin incision with minimal sternotomy approach to 78 pediatric patients who had undergone minimally invasive open heart surgery procedure with comparable cosmetic results $(8)$.

Less traumatic wounds provide patients more comfortable postoperative periods. Pain levels and daily life activities are the most important indicators for having physical and psychological well-being(5,7).

\section{CONCLUSION}

Minimally invasive cardiac surgery does not have worse mortality rates than standard techniques. However, it enables patients to return to their own normal activities, providing them with less wound complications. By increasing experiences, minimally invasive cardiac surgery may be considered in those

\begin{tabular}{|c|c|c|c|c|c|c|c|}
\hline Patient & Procedure & CCT (min) & CPBT(min) & OT (hour) & ICU (day) & Hospital (day) & Drainage (ml) \\
\hline \multicolumn{8}{|l|}{ Mini Sternotomy } \\
\hline 1 & AVR & 127 & 169 & 4 & 1 & 5 & 250 \\
\hline 2 & AVR & 87 & 139 & 8 & 2 & 11 & 150 \\
\hline 3 & AVR & 136 & 203 & 6 & 2 & 7 & 300 \\
\hline 4 & AVR & 120 & 240 & 10 & - & - & - \\
\hline \multicolumn{8}{|l|}{ Mini Thoracotomy } \\
\hline 1 & MVR, T Expl & 118 & 360 & 8 & 17 & 31 & 500 \\
\hline 2 & ASD Repair & 60 & 132 & 6 & 1 & 6 & 150 \\
\hline 3 & ASD Repair & 48 & 110 & 5 & 1 & 6 & 250 \\
\hline 4 & AVR, MVR & 170 & 203 & 8 & 2 & 7 & 400 \\
\hline 5 & M and T Repair & 97 & 131 & 7 & 5 & 7 & 500 \\
\hline 6 & CABG & $\mathrm{BH}$ & $\mathrm{BH}$ & 6 & 1 & 6 & 250 \\
\hline Mean & & 114.4 & 197.1 & 6.8 & 3.56 & 9.6 & 305 \\
\hline Standard Deviation & & 33.3 & 76.7 & 1.8 & 5.2 & 8.2 & 133 \\
\hline
\end{tabular}

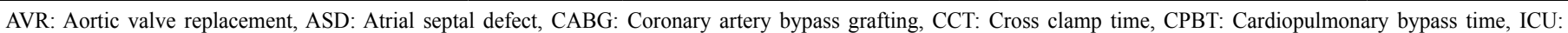
Intensive Care Unit, OT: Operation time, MVR: Mitral valve replacement, T Expl: Tricuspid exploration 
appropriate patients and particularly in patients who care about their own appearances.

\section{CONFLICT of INTEREST}

The authors reported no conflict of interest related to this article.

\section{REFERENCES}

1. Yoshimura N, Yamaguchi M, Oshima Y, Oka S, Ootaki Y, Yoshida M. Repair of atrial septal defect through a right posterolateral thoracotomy: a cosmetic approach for female patients. Ann Thorac Surg 2001;72:2103-5.

2. Gilmanov D, Bevilacqua S, Murzi M, Cerillo AG, Gasbarri T, Kallushi E, et al. Minimally invasive and conventional aortic valve replacement: a propensity score analysis. Ann Thorac Surg 2013;96:837-43.
3. Erentuğ V, Sareyüpoğlu B, Göksedef D, Kırali K, Güler M, Ippek G, et al Closure of atrial septal defects with anterior thoracotomy in female patients. Turk Gogus Kalp Dama 2005;13:99-102.

4. Totaro P, Carlini S, Pozzi M, Pagani F, Zattera G, D’Armini AM, et al Minimally invasive approach for complex cardiac surgery procedures. Ann Thorac Surg 2009;88:462-6.

5. Uymaz B, Sezer G, Köksal Coşkun P, Tarcan O, Ozleme S, Aybek T. Clinical outcome, pain perception and activities of daily life after minimally invasive coronary artery bypass grafting. Anadolu Kardiyol Derg 2014;14:172-7.

6. Smit PJ, Shariff MA, Nabagiez JP, Khan MA, Sadel SM, McGinn JT Jr. Experience with a minimally invasive approach to combined valve surgery and coronary artery bypass grafting through bilateral thoracotomies. Heart Surg Forum 2013;16:125-31.

7. Diegeler A, Walther T, Metz S, Falk V, Krakor R, Autschbach R, et al. Comparison of MIDCAP versus conventional CABG surgery regarding pain and quality of life. Heart Surg Forum 1999;2:290-6.

8. Fujiwara K, Naito Y, Komai H. (Lower mid-line skin incision and minimal sternotomy in pediatric open heart surgery-an alternative cosmetic approach). Nihon Geka Gakkai Zasshi 1998;99:837-41. 